\title{
Growth and Quality of Genotype PS-1319 Cacao Seedlings Produced Under Different Irrigation Depths
}

\author{
Stefany Sampaio Silveira ${ }^{1}$, Robson Prucoli Posse ${ }^{1}$, Sophia Machado Ferreira da Silva ${ }^{1}$, \\ Vinicius de Souza Oliveira ${ }^{2}$, Francielly Valani ${ }^{1}$, Regiane Lima Partelli ${ }^{1}$, Inês de Moura Trindade ${ }^{1}$, \\ Carlos Alberto Spaggiari Souza ${ }^{3}$, Sheila Cristina Prucoli Posse ${ }^{4}$, Geilson Silva Costa ${ }^{1}$, \\ Omar Schmildt ${ }^{2} \&$ Edilson Romais Schmildt ${ }^{2}$ \\ ${ }^{1}$ Federal Institute of Espírito Santo, Campus Itapina, Colatina, Espírito Santo, Brazil \\ ${ }^{2}$ Center Noth of Espírito Santo, Federal University of Espírito Santo, São Mateus, Espírito Santo, Brazil \\ ${ }^{3}$ Cacao Research Station "Filogônio Peixoto" (CEPLAC), Linhares, Espírito Santo, Brazil \\ ${ }^{4}$ Instituto Capixaba de Pesquisa, Assistência Técnica e Extensão Rural (INCAPER), Vitória, Espírito Santo, \\ Brazil \\ Correspondence: Vinicius de Souza Oliveira, Center Noth of Espírito Santo, Federal University of Espírito Santo, \\ São Mateus, Espírito Santo, Brazil. E-mail: souzaoliveiravini@gmail.com
}

Received: July 8, 2019

Accepted: August 14, 2019 Online Published: September 30, 2019

doi:10.5539/jas.v11n16p238

URL: https://doi.org/10.5539/jas.v11n16p238

\begin{abstract}
Due to the lack of information on the water demand of cocoa seedlings, empirical techniques have been used in the supply of water to the seedlings, potentializing losses in their growth and development. In this context, the present study aimed to determine the optimal irrigation depth for a good development of the genotype PS-1319 cocoa seedlings. The study took place at the Federal Institute of Espírito Santo-Campus Itapina, located in the Colatina, a city situated in the northwestern region of the state of Espírito Santo, Brazil, in an experimental greenhouse of the campus, between October 20 and December 15, 2017. The experiment was conducted in a completely randomized design (CRD) using 20 seedlings of the genotype PS-1319 cacao per treatment. The treatments consisted of daily applications of six irrigation depths, corresponding to 4, 6, 8, 10,12 and $14 \mathrm{~mm} \mathrm{~d}^{-1}$, being evaluated their effects on the morphological parameters (leaf area; dry mass of the aerial part, dry mass of the root system and total dry mass; height of the aerial part and stem diameter) and the quality (Dickson quality index). The applied depths interfered, both in the development and the quality of the seedlings, with quadratic adjustments for the leaf area, dry mass of the aerial part and total dry mass, diameter and for the Dickson quality index. The best responses to the studied parameters were provided by the $8.33 \mathrm{~mm} \mathrm{~d}^{-1}$ depth, which is recommended as an ideal for production of genotype PS-1319 cacao seedlings.
\end{abstract}

Keywords: Theobroma cacao L., vegetative development, water replacement, Dickson index, irrigation management

\section{Introduction}

The cacao tree (Theobroma cacao L.) belonging to the Malvaceae family is an essentially tropical tree, native of the American rainforest, cultivated between latitudes $20^{\circ} \mathrm{N}$ and $20^{\circ} \mathrm{S}$, at temperatures above $20^{\circ} \mathrm{C}$ throughout the year (Wood \& Lass, 1985; Landim et al., 1994; ITC, 2001; Souza et al., 2016). In Brazil, cacao cultivation was expanded by the banks of the Amazon River and introduced to Bahia in 1746, where it found good soil and climate conditions, forming the main producer region of the country and of great economic importance (Pamponet et al., 2012).

Cacao is among the highly energetic and stimulating foods, mainly in the use of its seeds for the production of chocolate and other by-products such as honey, jellies, butter, and cocoa powder (Vello et al., 1969; Smith et al., 1990), whose taste is a highly important characteristic, constituting the main reason for its consumption (Santos et al., 2000).

Cacao cultivation is constantly under threat from new diseases by a wide range of fungal pathogens (Bowers et al., 2001), which cause a loss of approximately one-third in the world production of cocoa (Lima et al., 2018). In Brazil, genotypes that are more resistant to these diseases have been researched by the Executive Committee of 
the Cacao Plantation Plan (CEPLAC), and one of them, the PS-1319, is indicated for cultivation in Espirito Santo state (Lavanhole, 2018).

The propagation of rootstocks for the cocoa crop is carried out predominantly by the seminal way, and the Common and TSH-1188 genotypes are currently the most used as rootstocks in Espirito Santo (Lavanhole, 2018). However, the expansion of the genetic base has great relevance in this segment, minimizing the risks of loss due to both biotic and abiotic factors, and one of the potential genotypes in this expansion is the PS-1319.

The quality of the cocoa seedlings used in the orchard formation is very important in its success, due to the perennial nature of the crop (Posse et al., 2018). One of the factors that greatly affect the growth and development of the seedlings is the adequate water supply (Ramos et al., 2015).

However, there is little information on the water demand of cocoa seedlings, which leads to the determination of irrigation depths based only on empirical criteria, by the nurserymen, thus making it difficult to manifest by changing their maximum genetic potential when taken to the field (Gruber, 2006; Ramos et al., 2015; Posse et al, 2018).

The hydrological and hydroclimatic information for cacao cultivation described in the literature are for the cultivation of adult plants, and there are no specific quotations for the seedlings production phase. In view of the above, this study aimed to determine the optimal irrigation depth for a good development of the genotype PS-1319 cacao seedlings.

\section{Method}

The research was carried out at the Federal Institute of Espirito Santo, Campus Itapina, located in Colatina, Northwest region of the state of Espírito Santo, Brazil, with geographic coordinates of $19^{\circ} 29^{\prime}$ South latitude, $40^{\circ} 45^{\prime}$ West longitude and altitude of 62 meters. The region has an irregular regime of rainfall with high temperatures, being classified as Tropical Aw, according to Köppen (1936).

The experiment was developed from seedlings of the genotype "PS-1319" cacao clone (Theobroma cacao L.), produced in tubes during spring (according to the seasons of the year, for the Southern Hemisphere), between October $20^{\text {th }}$ to December $15^{\text {th }}, 2017$.

The study was carried out inside an experimental greenhouse of the campus horticulture sector, with linear dimensions of $25 \mathrm{~m} \times 5 \mathrm{~m}$ and $3 \mathrm{~m}$ high, protected by transparent plastic film and black polypropylene screen with $50 \%$ shading.

Using some transparent plastic film, six individualized environments were created inside the greenhouse, each with $2.20 \mathrm{~m}$ length and $1.10 \mathrm{~m}$ width, according to the methodology of Posse et al. (2019). For each environment, there were installations of six NaanDanJain ${ }^{\circledR}$ GREEN MIST anti-mist nebulizers with $85 \%$ efficiency, located 1 $\mathrm{m}$ above the plants and spaced $0.8 \mathrm{~m} \times 0.8 \mathrm{~m}$ and a centrifugal pump of $0.5 \mathrm{hp}$, with a service pressure of 2.0 kgf.cm ${ }^{-2}$, working with pulses, controlled by electronic controllers and distributed daily in a period of $10 \mathrm{~h}$ (between 7 a.m and 5 p.m.)

The experiment was conducted using a completely randomized design (CRD), using 20 seedlings of the PS-1319 genotype cocoa per treatment, which consisted of the daily application of six irrigation depths, corresponding to 4, 6, 8, 10, 12 and $14 \mathrm{~mm} \mathrm{~d}^{-1}$.

For the production of the seedlings, tubes with $53 \mathrm{~mm}$ of diameter in the upper portion, $190 \mathrm{~mm}$ of height and capacity volumetric of $280 \mathrm{ml}$ were used. To prevent etiolation and to ensure adequate light delivery to the plants, according to their growth, the tubes were arranged in alternate cells on the 54 cell holders.

The tubes were pre-sterilized with $2 \%$ sodium hypochlorite diluted in water and then filled with Tropstrato $\mathrm{HT}^{\circledR}$ Vegetable substrate incorporated with Osmocote Plus ${ }^{\circledR} 15-9-12(3 \mathrm{M})$, at the dosage of $3 \mathrm{~g}$ tube ${ }^{-1}$, with the following chemical composition: $\mathrm{N}=15 \%,\left(7 \%\right.$ ammoniacal and $8 \%$ nitrate), $\mathrm{P}_{2} \mathrm{O}_{5}=9 \%, \mathrm{~K}_{2} \mathrm{O}=12 \%, \mathrm{Mg}=$ $1.3 \%, \mathrm{~S}=5.9 \%, \mathrm{Cu}=0.05 \%, \mathrm{Fe}=0.46 \%, \mathrm{Mn}=0.06 \%$ and $\mathrm{Mo}=0.02 \%$. No additional fertilization was performed.

The seeds of genotype PS-1319 cacao (Theobroma cacao L.) were obtained from the Experimental Station "Filogônio Peixoto"-belonging to CEPLAC (Executive Committee of the Cacao Plantation Plan), in Linhares/ES. The seeds were harvested from ripe fruits and the mucilage removed by rubbing sawdust powder. After this procedure, the seeds were planted, one per tube, about $2 \mathrm{~cm}$ deep.

During the period of the experiment, a Data Logger model 200 (WatchDog ${ }^{\circledR}$ ) was installed inside the greenhouse, allowing to obtain the average temperature and relative humidity and an ONSET $^{\circledR}$ weather station installed outside to the monitoring of climatic variations and the estimation of reference evapotranspiration (ETo) of the 
external environment through the Penman-Monteith method FAO-56 standard (Allen et al., 1998), Equation 1.

$$
\mathrm{ETo}=\frac{0.408 \Delta(\mathrm{Rn}-\mathrm{G})+\mathrm{y} \frac{90}{\mathrm{~T}+273} \mathrm{u}_{2}\left(\mathrm{e}_{\mathrm{s}}-\mathrm{e}_{\mathrm{a}}\right)}{\Delta+\mathrm{y}\left(1+0.34 \mathrm{u}_{2}\right)}
$$

Where, ETo is the daily reference evapotranspiration $\left(\mathrm{mm} \mathrm{d}^{-1}\right)$; Rn is the daily radiation balance (MJ $\left.\mathrm{m}^{-2} \mathrm{~d}^{-1}\right)$; $\mathrm{G}$ is the daily heat flux in the soil $\left(\mathrm{MJ} \mathrm{m}^{-2} \mathrm{~d}^{-1}\right)$; $\mathrm{T}$ is the daily average air temperature $\left({ }^{\circ} \mathrm{C}\right) ; \mathrm{u}_{2}$ is the daily average wind velocity at $2 \mathrm{~m}$ high $\left(\mathrm{m} \mathrm{s}^{-1}\right)$; es is the saturation pressure of the daily average water vapor $(\mathrm{kPa})$; ea is the daily average water vapor pressure $(\mathrm{kPa}) ; \Delta$ is the slope of the vapor pressure curve at the point of $\mathrm{T}\left(\mathrm{kPa}^{\circ} \mathrm{C}^{-1}\right)$ and $\gamma$ is the psychrometric coefficient $\left(\mathrm{kPa}{ }^{\circ} \mathrm{C}^{-1}\right)$.

The beginning of the evaluations occurred when $70 \%$ of the seedlings showed hook-like hypocotyl emergence on the substrate (October $28^{\text {th }}, 2017$ ). From then on, the following dates were recorded as days after emergence (DAE).

The following morphological parameters were evaluated at the end of the experimental period: leaf area (LA), expressed in $\mathrm{cm}^{2}$, estimated with LI-COR leaf area meter model LI-3100C; dry mass of the aerial part (DMAP), of the root system (DMRS) expressed in grams, by weighing them in an electronic scale with $0.001 \mathrm{~g}$ of precision, after being separately packed in paper bags and dried in stove with forced air circulation at $65^{\circ} \mathrm{C}$ up to constant weight; total dry mass (TDM), obtained by the sum of DMAP and DMRS and expressed in g; plant height $(\mathrm{PH})$, measured in $\mathrm{cm}$, using ruler graduated in millimeters, from the stem to the apical bud; Stem diameter (SD), measured $2 \mathrm{~cm}$ above the edge of the tube, in $\mathrm{mm}$, with a Metrotools digital caliper, model MPD-150; and Dickson quality index (DQI) according to (Dickson et al., 1960), through the Equation 2.

$$
\mathrm{DQI}=\frac{\mathrm{TDM}}{\left(\frac{\mathrm{PH}}{\mathrm{SD}}+\frac{\mathrm{DMAP}}{\mathrm{DMRS}}\right)}
$$

The data were submitted to analysis of variance by the $\mathrm{F}$ test at $1 \%$ of probability. When significant, to better describe the effect of applied irrigation depths on the studied parameters, regression models were adjusted. Statistical analyzes were performed using Software R (R Core Team, 2018).

\section{Results and Discussion}

The data of the meteorological parameters monitored during the production of the PS-1319 genotype cocoa seedlings registered average relative humidity in the interior of the agricultural greenhouse of $60.13 \%$, with average of the maximum and minimum relative humidity of the air of $85.80 \%$ and $34.46 \%$, respectively. The average of the temperatures observed in the agricultural greenhouse was $30.61{ }^{\circ} \mathrm{C}$ (Figure 1), with average of maximum and minimum temperatures of $39.08^{\circ} \mathrm{C}$ and $22.13{ }^{\circ} \mathrm{C}$, respectively (Figure 1).

Plant cultivation depends on optimum climatic conditions to manifest their genetic potential, especially aspects related to plant growth and development (Silva Neto et al., 2001). According to Taiz et al. (2017), for the plant growth is essential to preserve appropriate leaf temperatures, because the maximum photosynthetic rate occurs in a narrow temperature range.

Cacao growth and development, as occurs with other tropical tree species, is highly temperature dependent (Hadley et al., 1994). This can be observed by reducing the photosynthetic rates at temperatures above or below the range considered ideal (Raja \& Hardwick, 1988). Low temperatures affect mainly vegetative growth (Alvim, 1977), flowering (Alvim, 1988) and fruit development (Sale, 1969). 


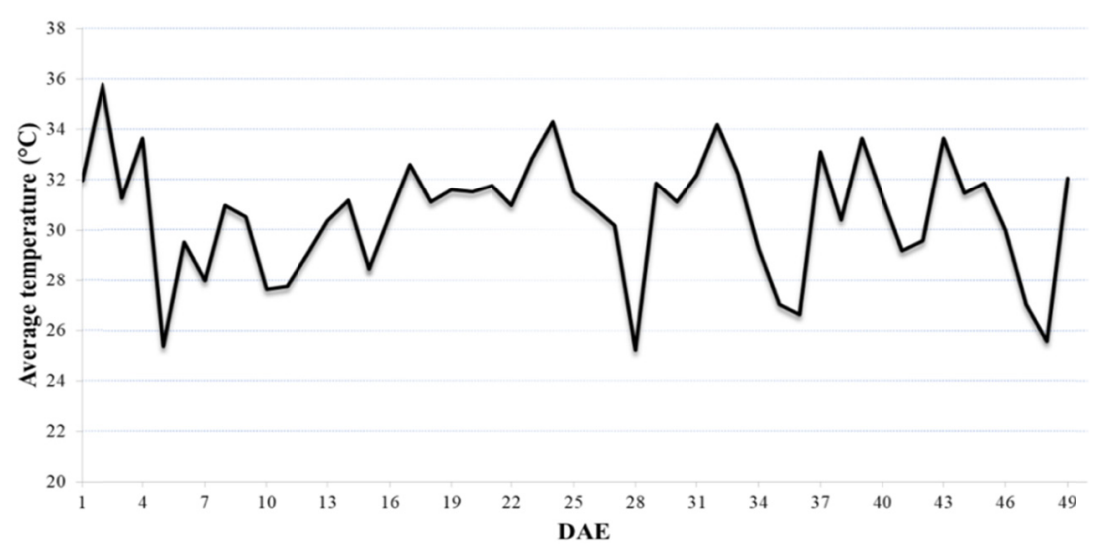

Figure 1. Daily values of the average temperature $\left({ }^{\circ} \mathrm{C}\right)$ recorded inside the agricultural greenhouse during the experimental production stage of genotype PS-1319 cacao seedlings

The average reference evapotranspiration (ETo), registered outside the agricultural greenhouse, was $3.37 \mathrm{~mm} \mathrm{~d}^{-1}$, with a maximum value of $6.63 \mathrm{~mm} \mathrm{~d}^{-1}$ being recorded on November $28^{\text {th }}, 2017,32$ days after emergency (DAE) (Figure 2).

The evapotranspiration of the crops represents an important research point for estimating the water consumption under different conditions and places, making the determination of water supplementation through irrigation more feasible (Matzenauer et al., 1998).

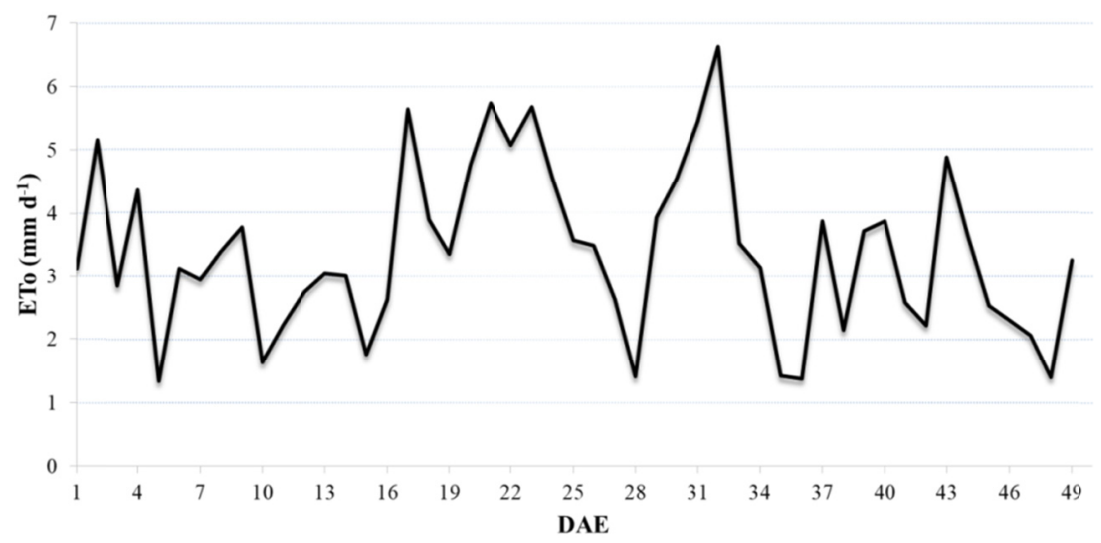

Figure 2. Daily values of the reference evapotranspiration (ETo), registered outside the agricultural greenhouse throughout the experimental production stage of genotype PS-1319 cacao seedlings

The leaf area presented linear second degree adjustment, with a maximum point of $152.35 \mathrm{~cm}^{2}$ in the irrigation depth of $9.11 \mathrm{~mm} \mathrm{~d}^{-1}$ and $\mathrm{R}^{2}$ of 0.745 (Figure 3). 


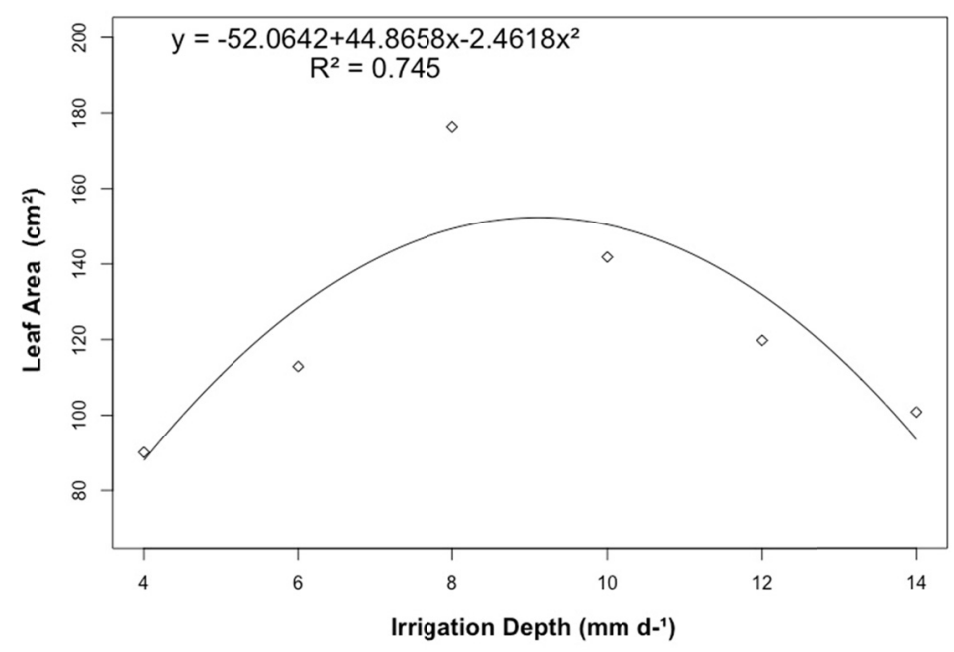

Figure 3. Leaf area (LA) of PS-1319 clonal cocoa in response to different irrigation depths

The availability of water has great importance in the growth, leaf expansion, photosynthetic activity and stomatal behavior of cacao plants (Lahive et al., 2018) and has made the current strand of water supply reduction in irrigation very challenging, due to its necessity to be done in order to meet the water requirements of the seedlings and not to compromise their development.

Greater leaf area provides greater light uptake to the plants for the accomplishment of photosynthesis, generating a greater amount of photoassimilates and, consequently, greater development and accumulation of dry mass (Melo et al., 2007). The dry mass of the aerial part, according to the irrigation depths used, had a quadratic behavior with a maximum point of $1.28 \mathrm{~g}$ in the depth of $8.19 \mathrm{~mm} \mathrm{~d}^{-1}$ and coefficient of determination $\left(\mathrm{R}^{2}\right)$ of 0.748 (Figure 4).

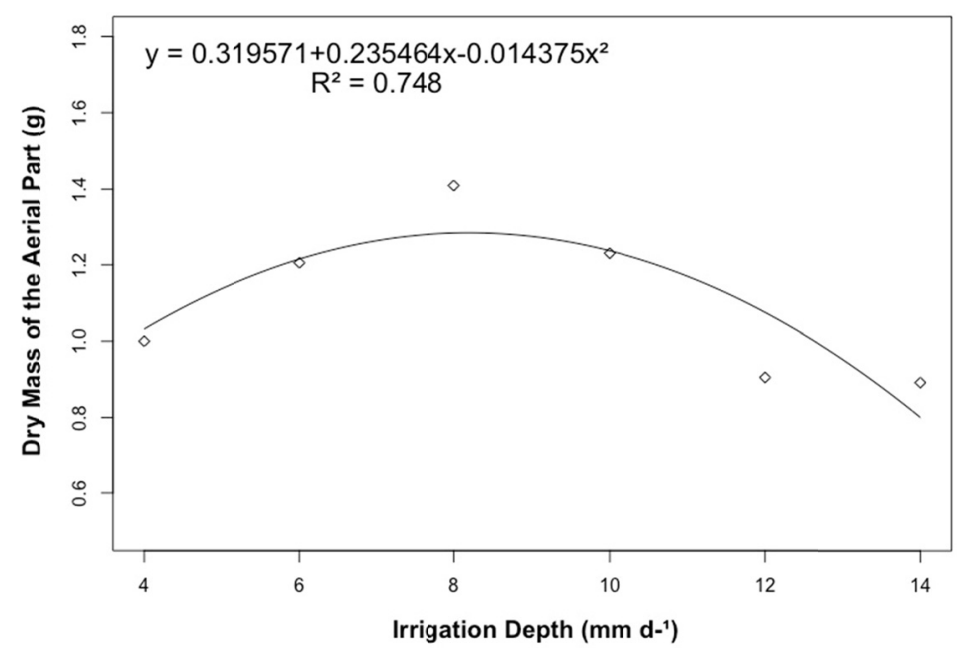

Figure 4. Dry mass of the aerial part (DMAP) of PS-1319 clonal cacao in response to different irrigation depths

The dry mass of the root system presented linear behavior of first degree decreasing in relation to the increase of the irrigation depth, with coefficient of $\mathrm{R}^{2}$ of 0.733 . This was evidenced by the decrease in mass from the applied depth of $10 \mathrm{~mm} \mathrm{~d}^{-1}$ (Figure 5). 


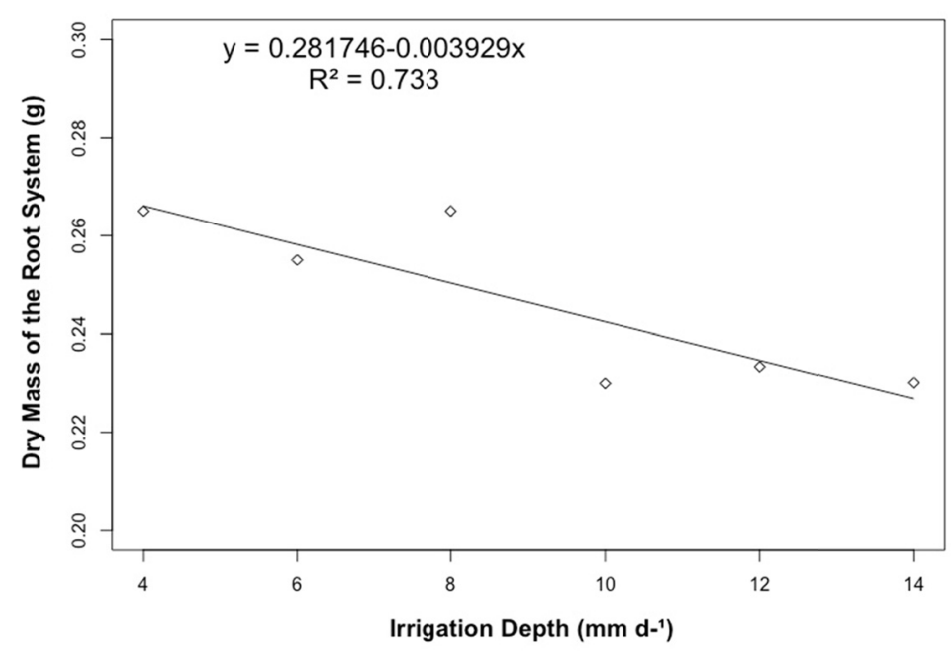

Figure 5. Dry mass of the root system (DMRS) of PS-1319 clonal cocoa in response to different irrigation depths

Reduced DMRS values on larger depths can be attributed to excessive irrigation which, in addition to causing excessive substrate drenching, may also leach nutrients (Thebaldi et al., 2016). This leaching occurs in a recurrent way in the conventional production of seedlings, because the application of water in the plants is often done without technical criteria by the producers, which can prevent the plant from reaching its genetic potential, causing decreases of productivity. On the other hand, the knowledge of the productive system of seedlings, in general, allows the elaboration of methods that optimize the production of seedlings with better quality, reducing the waste of water resources, energy and nutrients (Delgado et al., 2017).

The total dry mass expressed a quadratic behavior, showing the maximum point of $1.53 \mathrm{~g}$ in the irrigation depth of $8.05 \mathrm{~mm} \mathrm{~d}^{-1}$ and coefficient of determination $\left(\mathrm{R}^{2}\right)$ of 0.894 (Figure 6).

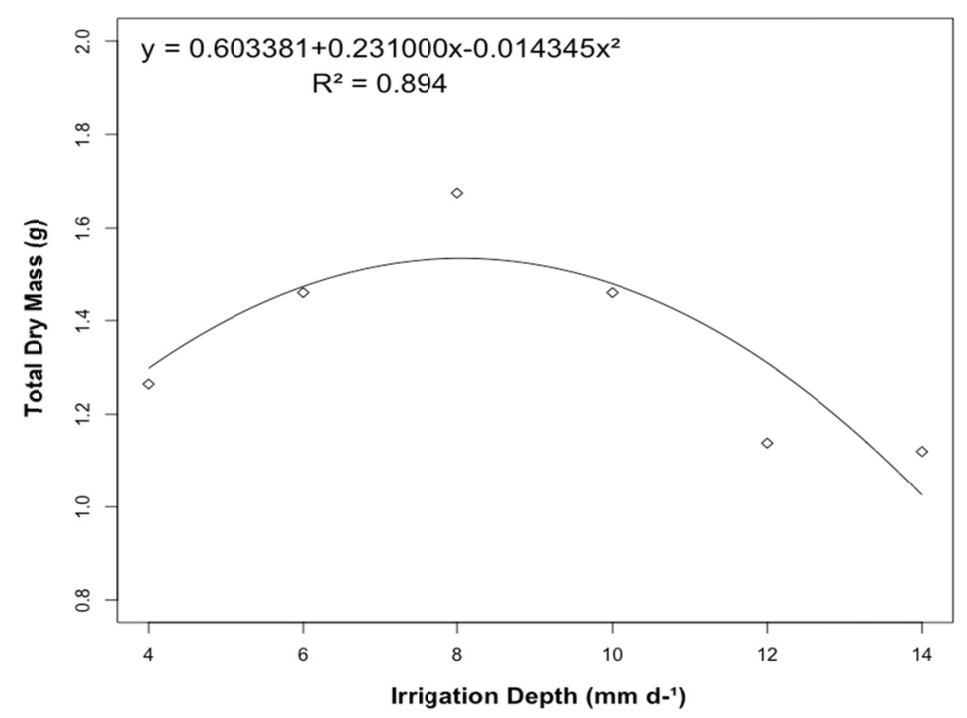

Figure 6. Total dry mass (TDM) of PS-1319 clonal cocoa in response to different irrigation depths

Matos (1972), studying the effects of different substrates and irrigation regimes on the development of cocoa seedlings, concluded that daily irrigation is the most adequate regime for the root development and in which the seedlings presented higher production of dry matter. Ramos et al. (2015), evaluating the development of seedlings of the PH-16 clone cocoa related to the different irrigation depths in a substrate with a bark of Pinus $\left(\right.$ Plantmax $\left.^{\circledR}\right)$ and coconut fiber, observed that when increased the amount of water applied, there was a proportional increase in total dry matter.

The height of the plant presented a linear adjustment of first degree decreasing in relation to the increase of the 
irrigation depth, with coefficient of determination $\left(\mathrm{R}^{2}\right)$ of 0.782 (Figure 7).

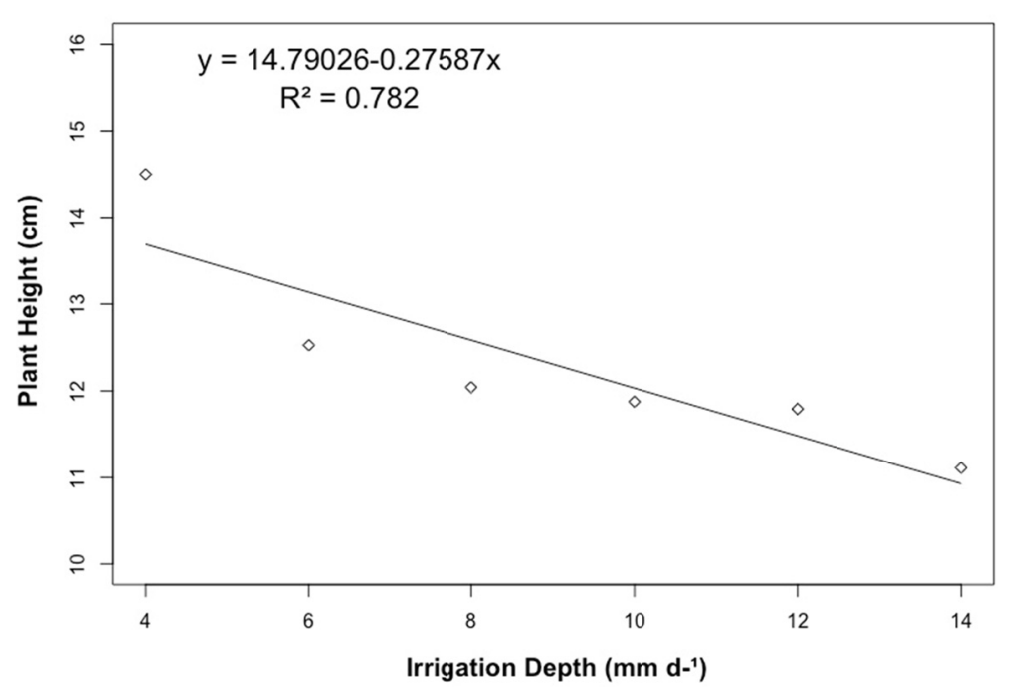

Figure 7. Plant height (PH) of PS-1319 clonal cacao in response to different irrigation depths

For Dassie et al. (2017), morphological characteristics of easy measurement, such as plant height and stem diameter, are the most used as the basis for the evaluation of the transplanting point of the seedling to the field, being desirable the highest values. However, in spite of the highest height of the seedlings, occurred in response to the application of the $4 \mathrm{~mm} \mathrm{~d}^{-1}$ depth, the other characteristics evaluated in this experiment for this one had lower responses than the other depths, which indicates the occurrence of etiolation, possibly by the expenditure of all its initial energy in the development of its length.

The stem diameter presented quadratic behavior with the largest diameter of $3.91 \mathrm{~mm}$ in the irrigation depth of $8.96 \mathrm{~mm} \mathrm{~d}^{-1}$ and $\mathrm{R}^{2}$ of 0.894 . The smallest diameter was observed in the treatment with $14 \mathrm{~mm} \mathrm{~d}^{-1}$, in which a value of $4.74 \mathrm{~mm}$ was obtained (Figure 8).

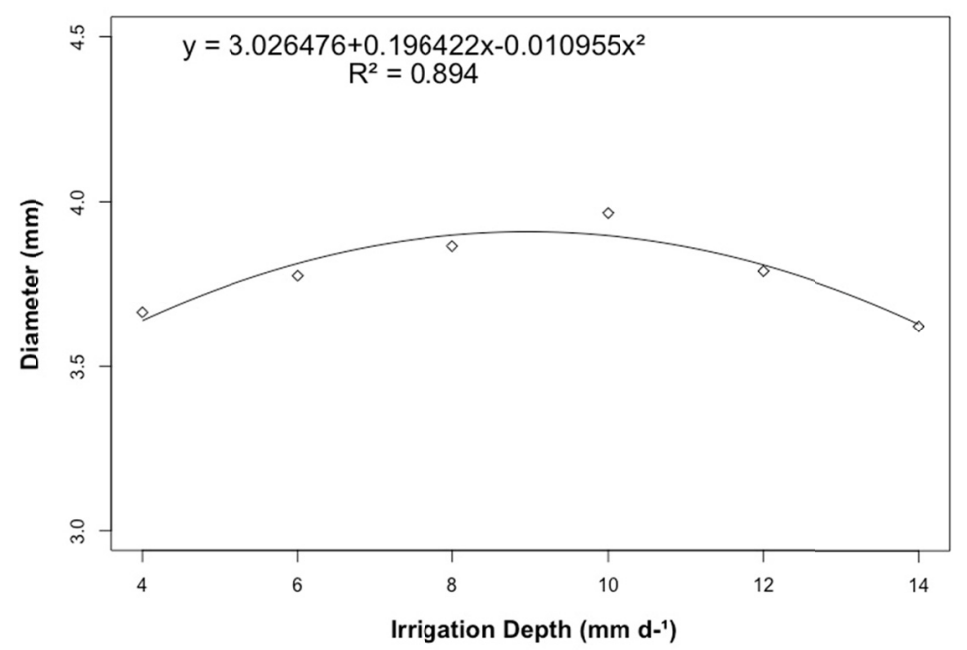

Figure 8. Stem diameter (SD) of PS-1319 clonal cacao in response to different irrigation depths

The diameter development responses to the applied depths showed a limitation in the formation of seedlings due to water deficiency, fact also observed in the work with cocoa seedlings performed by Ramos et al. (2015), who found a positive linear performance of the diameter due to the applied depth.

The Dickson quality index showed a quadratic behavior with the highest index of 0.19 in the irrigation depth of 
$8.33 \mathrm{~mm} \mathrm{~d}^{-1}$ and the regression model presented coefficient of determination $\left(\mathrm{R}^{2}\right)$ of 0.894 (Figure 9).

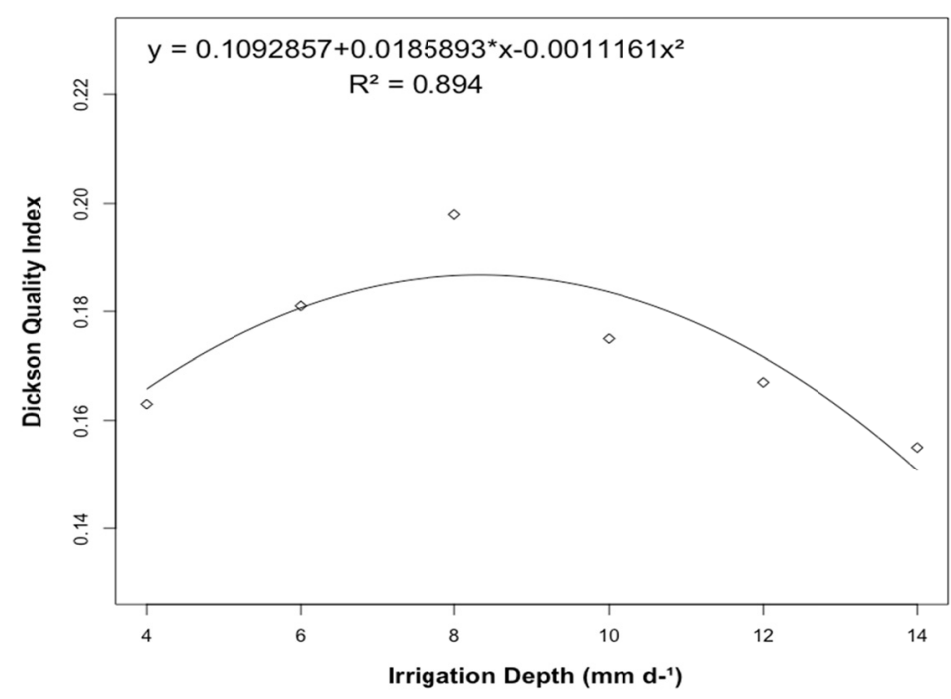

Figure 9. Dickson quality index (DQI) of PS-1319 clonal cacao in response to different irrigation depths

Dickson quality index (DQI) is a recommended parameter and considered useful for verifying the quality of seedlings (Binotto, 2007) and understanding the several morphological features such as total dry mass, relation between the height of the aerial part and the stem diameter (RHD) and between the dry mass of the aerial part and the dry mass of the root system (RAPRS) (Sánchez et al., 2012).

Evaluating the quality of seedlings of Trema micrantha (L.) Blume, Fonseca et al. (2002), confirm that the Dickson quality index is strongly associated with all plant morphological parameters. Researching on the biometric development of eucalyptus seedlings under different irrigation depths in the growing phase, Silva et al. (2015), found that for clone A, the daily gross depths of 11 and $14 \mathrm{~mm}$ allowed high quality seedlings with DQI $=0.24$. On the other hand, genetic material B expressed a higher Dickson quality index for the $15 \mathrm{~mm}$ depth at the end of the evaluation period.

According to Hunt (1990), for the production of quality seedlings it is necessary that the value of DQI be higher or equivalent to 0.2 . The irrigation depth of $8.33 \mathrm{~mm} \mathrm{~d}^{-1}$ showed an approximate value $(0.19)$, showing that it is indicated as the ideal for the qualified production of seedlings of genotype PS-1319 cacao.

\section{Conclusion}

Irrigation depths interfere with the growth and quality of the genotype PS-1319 cacao seedlings. In their production, the irrigation depth of $8.33 \mathrm{~mm} \mathrm{~d}^{-1}$ results in better development and higher quality, which should be considered in irrigation management.

\section{References}

Allen, R. G., Pereira, L. S., Raes, D., \& Smith, M. (1998). Crop evapotranspiration: Guidelines for computing crop water requirements. Irrigation and Drainage Paper, 56 (pp. 1-300). Rome: FAO.

Alvim, P. T. (1977). Cacao. In P. T. Alvim, \& T. T. Kozlowski (Eds.), Ecophysiology of Tropical Crops. Academic Press, London. https://doi.org/10.1016/B978-0-12-055650-2.50015-0

Alvim, P. T. (1988). Relações entre fatores climáticos e produção do cacaueiro. Proc. $10^{\text {th }}$ Int. Cocoa Res. Conf. Santo Domingo, Dominican Republic.

Binotto, A. F. (2007). Relation between growth variability and Dickson quality index in Eucalyptus grandis W. Hill ex Maid e Pinus elliottii var. Elliottii-Engelm seedlings (56 f., Master Dissertation, Federal University of Santa Maria, Santa Maria, Brazil).

Bowers, J. H., Bailey, B. A., Hebbar, P. K., Sanogo, S., \& Lumsden, R. D. (2001). The impact of plant diseaseson on world chocolate production. Plant Health Progress. https://doi.org/10.1094/PHP-20010709-01-RV 
Dassie, L. A., Aleman, C. C., Moreira, A. C. M., Mignacca, F. A., Zanfolin, P. R. L., \& Carvalho, P. R. (2017). Irrigated production of pepper finger seedlings (Capsicum baccatum). Colloquium Agrariae., 13(3), 128-131. https://doi.org/10.5747/ca.2017.v13.n3.a182

Delgado, L. G. M., Silva, R. B. G., \& Silva, M. R. (2017). Qualidade morfológica de mudas de ingá sob diferentes manejos hídricos. Irriga Botucatu, 22(3), 420-429. https://doi.org/10.15809/irriga.2017 v22n3p420-429

Dickson, A., Leaf, A. L., \& Hosner, J. F. (1960). Quality appraisal of white spruce and white pine seedling stock in nurseries. Forestry Chronicle, 36, 10-13. https://doi.org/10.5558/tfc36237-3

Fonseca, É. P., Valéri, S. V., Miglioranza, É., Fonseca, N. A. N., \& Couto, L. (2002). Target seedlings of Trema micrantha (L.) Blume grown under different periods of shading. Tree Magazine, 26(4),515-523. https://doi.org/10.1590/S0100-67622002000400015

Gruber, Y. B. G. (2006). Optimization of irrigation depth in the production of seedlings clone of eucalypts (Eucaliptus urophylla $\times$ Eucaliptus grandis and Eucaliptus urophylla var. plathyphylla) (144f., Master Dissertation, University of Superior Agriculture Luiz de Queiroz; Piracicaba, Brazil).

Hadley, P., End, M., Taylor, S. T., \& Pettipher, G. L. (1994). Environmental regulation of vegetative and reproductive growth in cocoa grown in controlled glasshouse conditions. Proc. $11^{\text {th }}$ Int. Cocoa Res. Conf. Yamoussoukro, Côte D'Ivoire.

Hunt, G. A. (1990). Effect of styroblock design and cooper treatment on morphology of conifer seedlings. In R. Rose, S. J. Campbell, \& T. D. Landis (Eds.), Target Seedling Symposium, Meeting of the Western Forest, Roseburg. Proceedings... Collins: United States Departament of Agriculture, Forest Service.

ITC (International Trade Centre). (2001). Cocoa: A guide to trade practices. Geneva: ITC/UNCTAD/WTO. https://doi.org/10.18356/3f4daa51-en

Köppen, W. (1936). Das geographische system der klimate. In G. W. Köppen \& M. R. Geiger (Eds.), Handbuch der Klimatologie. Berlin: Gebrüder Bornträger.

Lahive, F., Hadley, P., \& Daymond, A. J. (2018). The impact of elevated $\mathrm{CO}_{2}$ and water deficit stress on growth and photosynthesis of juvenile cacao (Theobroma cacao L.). Photosynthetica, 56(3), 911-920. https://doi.org/10.1007/s11099-017-0743-y

Landim, A. D., Barroco, H. E., Ferreira, H. S., \& Nascimento, F. R. (1994). The cocoa crop crisis: Its nature and solutions an analysis of the possibilities of cocoa. Brasília: IPEA.

Lavanhole, D. F. (2018). Characterization of fruits and seeds and ecophysiology of germination of Theobroma cacao L. (66 f., Master Dissertation, Federal University of Espirito Santo, Espirito Santo, Brazil).

Lima, S. S., Souza, C. A. S., Patrocínio, N. G. R. B., Silva, R. A., Santos, R. S. G., \& Gramacho, K. P. (2018). Favorability, distribution and prevalence of witches broom disease of cacao in the State of Espirito Santo, Brazil. Agrotrópica, 30(1), 5-14. https://doi.org/10.21757/0103-3816.2018v30n1p5-14.pdf

Matos, A. (1972) Effects of different substrates and irrigation regimes in the development of cacao seedlings (Theobroma cacao L.) (Master Dissertation, Universidade Federal de Viçosa, Viçosa, Brazil).

Matzenauer, R., Bergamaschi, H., \& Berlato, M. A. (1998). Crop maize evapotranpiration. II-Ratios between the evapotranspiration to Class A Pan evaporation, to the reference evapotranspiration and to global solar radiation, at three sowing dates. Brazilian Journal of Agrometeorology, 6(1), 15-21.

Melo, A. S., Costa, C. X., Brito, M. E. B., Viégas, P. R. A., \& Silva Júnior, C. D. (2007). Production of papaya seedlings in different substrates and phosphorus levels. Brazilian Journal of Agricultural Sciences, 2(4), 257-261. https://doi.org/10.5039/agraria.v2i4a1838

Pamponet, B. M., Oliveira, A. S., Marinho, L. B., Vellame, L. M., \& Paz, V. P. S. (2012). Natural termal diferences sap flow estimating by the granier's method, in cocoa full sun and under water deficit. Irriga, Special, 120-132. https://doi.org/10.15809/irriga.2012v1n01p120

Posse, R. P., Silveira, S. S., Ferreira, S. M., Valani, F., Jaske, R., Miranda, C. A. C., Trindade, I. M., \& Scaldaferro, S. G. (2019). Development of seedlings of cacao genotype Comum Bahia produduced in autumn under different irrigation blades. In A. M. Zuffo (Eds.), The Production of Knowledge in Agrarian and Environmental Sciences 2. Atena Publisher, Ponta Grossa. https://doi.org/10.22533/at.ed.852192604 
Posse, R. P., Valani, F., Souza, C. A. S., Silveira, S. S., Silva, S. M. F., Partelli, R. L., .. Costa, G. S. (2018). Growth and quality of Genotype TSH1188 cacao tree seedlings produced under different seasons and irrigation depths. Journal of Experimental Agriculture International, 28(2), 1-17. https://doi.org/10.9734/ JEAI/2018/44718

R Core Team. (2018). R: A language and environment for statistical computing. Vienna: R Foundation for Statistical Computing, Vienna, Austria.

Raja, H. R. M., \& Hardwick, K. (1988). The effect of different temperatures and water vapour pressure deficits on photosynthesis and transpiration of cocoa leaves. Proceedings of the $10^{\text {th }}$ International Cocoa Research Conference. Santo Domingo, Dominican Republic.

Ramos, A., Sodré, G. A., Porto, J. S., \& Costa, R. Q. (2015). Development of cocoa seedlings in different watering. Agrotrópica, 27(1), 19-24. https://doi.org/10.21757/0103-3816.2015v27n1p19-24

Sale, P. J. M. (1969). Extension growth of cacao under controlled temperature conditions. Journal of Horticultural Science, 44(2), 4189-4193. https://doi.org/10.1080/00221589.1969.11514297

Sánchez, A. R., Solorio, J. D. B., Prieto-Ruiz, J. A., Reyez, T. S., Orozco-Gutiérrez, G., \& Castañaeda, A. M. (2012). Quality of plants produced in forest nurseries in Jalisco. Mexican Magazine of Fores Sciencer, 3(14), 69-82. Retrieved from http://www.scielo.org.mx/pdf/remcf/v3n14/v3n14a6.pdf

Santos, R. C. (2000). BRS 151 L-7: A new peanut cultivar recommended to the brazilian northeast conditions. Brazilian Agricultural Research, 35(3), 665-670. https://doi.org/10.1590/S0100-204X2000000300025

Silva Neto, P. J., Matos, P. G. G., Martins, A. C. S., \& Silva, A. P. (2001). Cacao production system for the Brazilian Amazon. Belém: Ceplac.

Silva, C. R. A., Ribeiro, A., Oliveira, A. S., Klippel, V. H., \& Barbosa, R. L. P. (2015). Biometric developmet of eucalyptus seedlings under different irrigation depths in growth stage. Journal of Forestry Research, 35(84), 381-390. https://doi.org/10.4336/2015.pfb.35.84.897

Smith, F. G. E. (1990). Cacao cultivation in the State of Espirito Santo. Ilhéus: CEPLAC/CEPEC.

Souza, C. A. S., Dias, L. A. S., \& Aguilar, M. A. G. (2016). Economic and social importance. In C. A. S. Souza, L. A. S. Dias, M. A. G. Aguilar, In A. Borem (Eds.), Cacao from planting to harvest (1st ed., pp. 9-40) Viçosa, MG: UFV. https://doi.org/10.1590/1982-3533.2016v25n1art7

Taiz, L., Zeiger, E., Moller, I. M., \& Murphy, A. (2017). Fisiologia e desenvolvimento vegetal (6th ed.). Porto Alegre: Artmed.

Thebaldi, M. S., Lima, L. A., Silva, A. C., Colares, M. F. B., \& Lima, P. L. T. (2016). Irrigation efficiency on native forest seedlings grown in recipient tubes. Forest Sceirnce, 26(2), 401-410. https://doi.org/10.5902/ 1980509822741

Vello, F., Mariano, A. H., Garcia, J. R., Nascimento, T. F., \& Magalhães, W. S. (1969). O programa de melhoramento genético do cacau na Bahia. Conferencia Internacional de Pesquisas em Cacau, Salvador. Memórias, CEPLAC.

Wood, G. A. R., \& Lass, R. A. (1985). Cocoa (4th ed.). Londres: Blackwell Science.

\section{Copyrights}

Copyright for this article is retained by the author(s), with first publication rights granted to the journal.

This is an open-access article distributed under the terms and conditions of the Creative Commons Attribution license (http://creativecommons.org/licenses/by/4.0/). 